\title{
Education sector response to early and unintended pregnancy (EUP): A review of country experiences in East and Southern Africa
}

Harriet Birungi

Population Council

Chi-Chi Undie

Population Council

Francis Onyango

Population Council

Follow this and additional works at: https://knowledgecommons.popcouncil.org/departments_sbsr-rh

Part of the Education Policy Commons, International Public Health Commons, Maternal and Child Health Commons, and the Women's Health Commons

How does access to this work benefit you? Let us know!

\section{Recommended Citation}

Birungi, Harriet, Chi-Chi Undie, and Francis Onyango. 2014. "Education sector response to early and unintended pregnancy (EUP): A review of country experiences in East and Southern Africa," presentation at Global Consultation on Education Sector Response to Early and Unintended Pregnancy. 


\section{Education Sector Response to Early and Unintended Pregnancy (EUP): A Review of Country Experiences in East and Southern Africa}

Harriet Birungi, Chi-Chi Undie, Francis Onyango

Population Council, Nairobi Office

Global Consultation on Education Sector Response to Early and Unintended Pregnancy

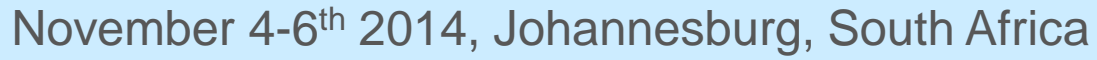

Organized by UNESCO, UNFPA, Ford Foundation, Population Council/STEP UP

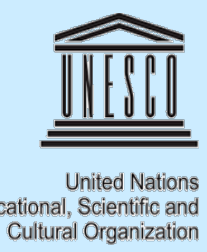




\section{Why this review was necessary}

- Because, the limited evidence available tells us that early and unintended pregnancy is widespread throughout the region

\section{But}

- Limited knowledge of

- How the education sector is responding to the issue; and

- Whether education sector response is adequate 


\section{UNESCO's four pillar response to EUP}

- Providing all young people with good quality Comprehensive Sexuality Education (CSE). (including education on pregnancy, prevention and contraception)

- Ensuring pregnant and childbearing girls the right to education - development and effective implementation of re-entry policies

- Increasing adolescent access to health education and services (including contraception) through the establishment of a referral system between schools and health facilities

- Eliminating stigma and discrimination toward pregnant and childbearing girls in schools and communities 


\section{Aim}

$\square$ Examine education sector response to EUP in Six ESA countries (Botswana, Kenya, Malawi, Tanzania, Uganda, Zambia), with a focus on:

o Education sector policies for pregnant learners and student mothers

o Integration of CSE into life skills education curricula

o School environment as it pertains to pregnant students (stigma/discrimination, health facility linkages)

o Education sector efforts to improve gender equality 


\section{Methods}

$\square$ Study duration: 3 months (Aug-Oct 2014)

$\square$ DHS secondary analysis

$\square$ Desk review of existing literature

- Documents provided by UNESCO staff \& associates

- Google search focusing on (for example):

- life skills,

- sexuality education,

- re-entry policy, readmission,

- gender equality, gender equity, gender parity, gender policies, affirmative action,

- education sector policies, school health policies 


\section{Early pregnancy among girls 15-19}

\begin{tabular}{|c|c|c|}
\hline Country & Ever pregnant (\%) & $\begin{array}{c}\% \text { out of school } \\
\text { among ever } \\
\text { pregnant }\end{array}$ \\
\hline Botswana & $\mathrm{n} / \mathrm{a}$ & $n / a$ \\
\hline Kenya & 18 & 98 \\
\hline Malawi & 26 & 97 \\
\hline Tanzania & 23 & 99 \\
\hline Uganda & 24 & 98 \\
\hline Zambia & 28 & 95 \\
\hline \multicolumn{3}{|c|}{ Source: Demographic and Health Survey; n/a: Most recent data not available } \\
\hline
\end{tabular}




\section{High unintended pregnan
among girls 15-19 years}

\begin{tabular}{|l}
\hline Country \\
\hline Botswana \\
\hline Kenya \\
\hline Malawi \\
\hline Tanzania \\
\hline Uganda \\
\hline Zambia \\
\hline
\end{tabular}

Unintended

Pregnancy (\%)

n/a

59

44

39

47

58

Source: Demographic and Health Survey; n/a: Most recent data not available
A LARGE PROPORTION OF CLIENTS SEEKING POSTABORTION SERVICES AT HEALTH FACILITIES ARE $<19$ YEARS

17\% (Kenya),

21\% (Malawi), 49\%-58\% (Tanzania), $60 \%$ (Zambia), 68\% (Uganda)

(Source Guttmacher Institute 2009; Levandowski et al. 2009; Mirembe 1996; Rasch and Kipingili 2009; Republic of Kenya 2013).

KENYA: 45\% OF WOMEN AGED <19 \& 47\% STUDENTS EXPERIENCE SEVERE UNSAFE ABORTION COMPLICATIONS

(Source: MOH. 2013 Incidence and complications of Unsafe abortion in Kenya) 


\section{Country education sector policies \& practices}

\begin{tabular}{|c|c|c|c|c|c|c|}
\hline Country & Relevant Policies & Policy Practices & $\begin{array}{l}\text { Pregnancy } \\
\text { Screening }\end{array}$ & $\begin{array}{l}\text { Re-entry } \\
\text { Practices }\end{array}$ & $\begin{array}{l}\text { Pregnant Girls } \\
\text { Allowed in } \\
\text { School? }\end{array}$ & Policy status \\
\hline Botswana & $\begin{array}{l}\text { Botswana Education } \\
\text { Regulations (1978) }\end{array}$ & Re-entry & Yes & 12 month f absence & No & Established \\
\hline \multirow[t]{2}{*}{ Kenya } & $\begin{array}{l}\text { Return to School Policy } \\
\text { Guidelines (1998) }\end{array}$ & Re-entry & No & Unclear & No & $\begin{array}{l}\text { Established } \\
\text { (Return to School } \\
\text { Policy, 1994) }\end{array}$ \\
\hline & $\begin{array}{l}\text { National School Health } \\
\text { Policy (2009) }\end{array}$ & Re-entry & Yes & 6 months & Yes & Established \\
\hline Malawi & $\begin{array}{l}\text { MOEVT Readmission } \\
\text { Policy (1993) }\end{array}$ & Re-entry & Unknown & $\begin{array}{l}12 \text { month suspension, } \\
\text { re-entry into next } \\
\text { academic year }\end{array}$ & No & $\begin{array}{l}\text { Revised Re-entry } \\
\text { Guidelines in Draft } \\
\text { Form }\end{array}$ \\
\hline \multirow[b]{2}{*}{ Tanzania } & $\begin{array}{l}\text { No official policy (current } \\
\text { practice) }\end{array}$ & Expulsion & Yes & N/A & No & $\mathrm{N} / \mathrm{A}$ \\
\hline & $\begin{array}{l}\text { Draft Re-entry Guidelines } \\
\text { (yet to be approved) }\end{array}$ & Re-entry & Yes & $\begin{array}{l}\text { After 6-12 month } \\
\text { suspension }\end{array}$ & No & Draft \\
\hline \multirow[t]{2}{*}{ Uganda } & $\begin{array}{l}\text { No official policy (current } \\
\text { practice) }\end{array}$ & $\begin{array}{l}\text { Suspension } \\
\text { Expulsion } \\
\text { Re-entry at } \\
\text { different schools }\end{array}$ & Yes & $\begin{array}{l}\text { Left to discretion of } \\
\text { head teacher }\end{array}$ & No & N/A \\
\hline & & Re-entry & Yes & Unclear & Yes & Draft \\
\hline Zambia & $\begin{array}{l}\text { MOE Re-entry Policy } \\
\text { (1997) }\end{array}$ & Re-entry & Yes & $\begin{array}{l}12 \text { month leave of } \\
\text { absence }\end{array}$ & Yes & Established \\
\hline
\end{tabular}




\section{Categorization of policies \&practices}

Chilisa (2002) provides three different types of policies and practices directed towards pregnant learners:

- Expulsion - immediate removal from the school system with no prospect of returning

- Re-entry - compulsory leave of absence before a student may re-enter school

- Continuation - allows pregnant learner allowed to remain in school for as long as they would like 


\section{Policies and practices in summary}

- None of the six countries utilize a continuation policy for school re-entry

- Only three countries (Botswana, Kenya, Zambia) have official, established school re-entry policies

- Malawi, Tanzania, Uganda have draft re-entry policies

- Policy confusion exists within countries, with various education sector policies conflicting with one another

- Pregnancy screening happens in All countries, but with no obvious good benefit

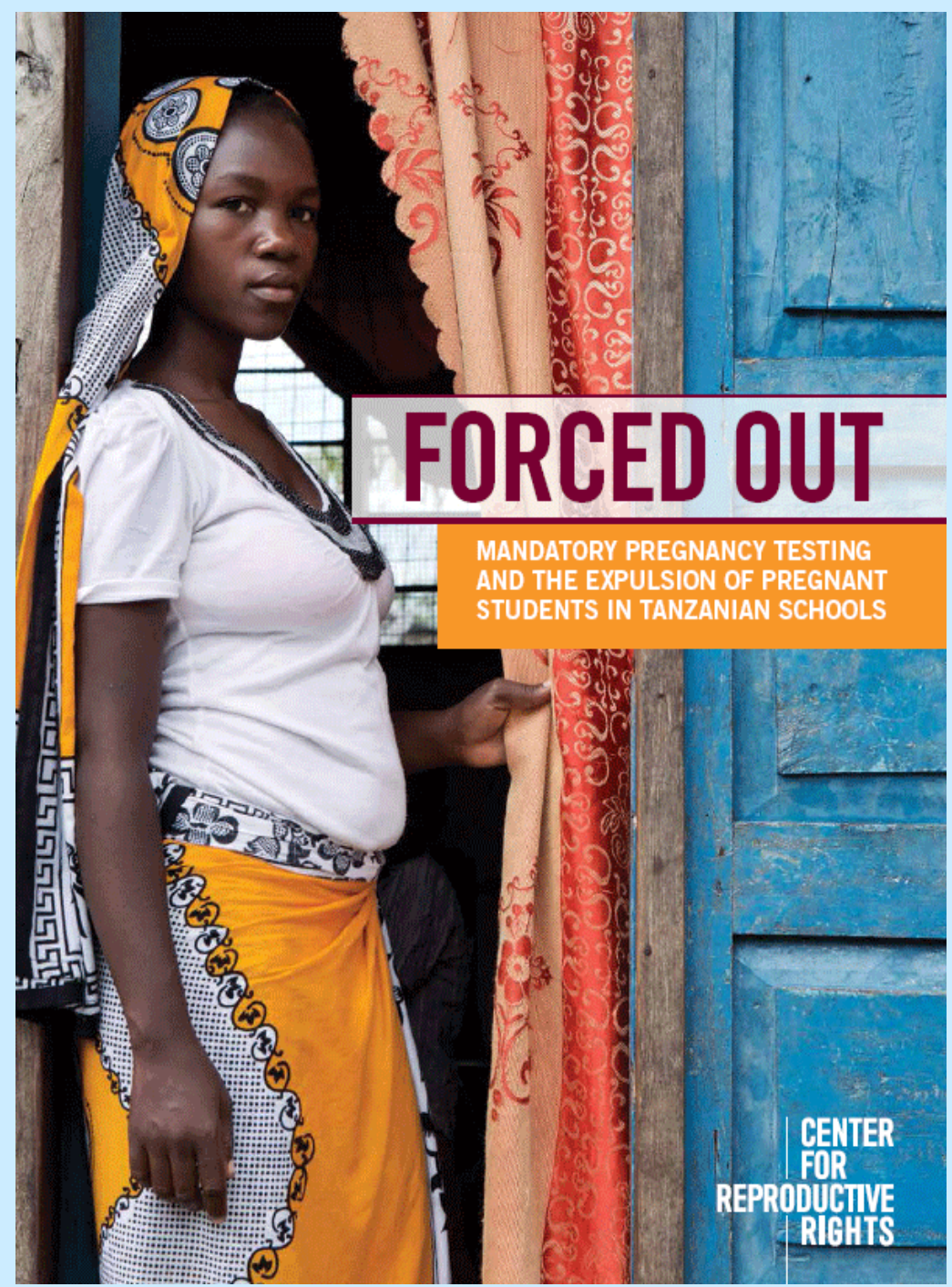




\section{CSE and life skills education: Is the content adequate?}

- None of the six countries are offering CSE as defined by UNESCO

- Pregnancy prevention (including condoms \& contraceptives) NOT a central feature of the CSE content

- Condoms taught in Botswana, Malawi \& Uganda

- LSE content on contraceptives

- Included in Zambia (new), No information on contraceptives (Kenya, Malawi).

- Unclear whether LSE includes contraceptives (Botswana, Tanzania)

- Included in Uganda (only in Islamic Religious curriculum)

- When offered at all, pregnancy prevention covered at secondary school level alone 


\section{School environment}

- Stigma and discrimination (schools and communities) remains a pervasive barrier to resuming education

- Few interventions exist - Malawi, Kenya

- Lack of school-health facility linkages

- Limited school level structures to support students mothers

- Interventions don't end up being institutionalized 


\section{Gender equity}

- Policies on free primary \& secondary education helped close the gender parity gap

But

- Girls continue to have lower completion rates in secondary school than boys

- All countries have gender elements and sensitivities built into LSE, but some efforts tend to be counterproductive 


\section{Conclusion}

- Existence of policies to promote education sector response demonstrates commitment by the countries.

- As recently as 2013, Education \& Health Ministers in ESA confirmed their commitment to address early and unintended pregnancy

However,

- Current responses are extremely inadequate

- Practices, gaps and inconsistencies outlined constitute a violation of pregnant learners' rights to education 


\section{Recommendations}

- Review national variations in re-entry policies and facilitate harmonization

- Prototype guidance document on education sector response needed to enhance awareness of what responses ought to be

- Widely popularized among education and health sector stakeholders

- LSE/CSE curricula should be expanded to include content on pregnancy prevention, with stipulations for this info to be provided as early as Upper Primary levels to reduce UP, unsafe abortion, school dropout

- Promote \& support linkages between education and health - integrated school health program that encompass preventive and treatment services need to be developed and tested

- Promising programs to support school re-entry should be identified, assessed and consolidated with a view to institutionalizing and scaling up 


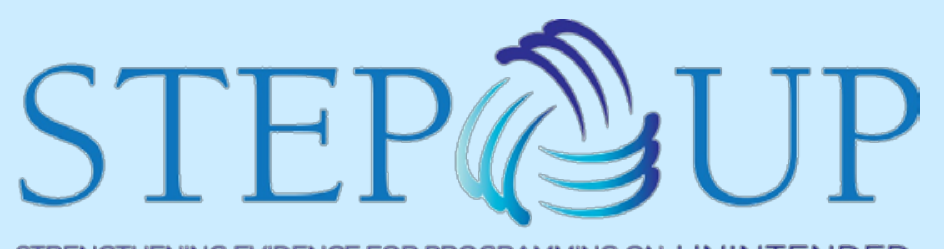

The STEP UP (Strengthening Evidence for Programming on Unintended Pregnancy) Research Programme Consortium is coordinated by the Population Council in partnership with the African Population and Health Research Center; icddr,b; the London School of Hygiene and Tropical Medicine; Marie Stopes International; and Partners in Population on Development. STEP UP is funded by UK aid from the UK Government. www.stepup.popcouncil.org

\section{Thank you!}

